\title{
Starting 2012 with an Academic Feast
}

Dear fellow academicians; the just concluded PEDICON at Gurgaon must have rejuvenated and satisfied the satiety of your ever-demanding grey cells. You must have enjoyed along with academics, socio-cultural extravaganza, maybe a family holiday in the foggy-chilly mornings at Gurgaon. By now you must have adapted back to your routine office/hospital practice taking care of the tiny-tots.

For those who could not attend PEDICON for varied reasons, it was definitely one of the best, professionally managed, scientifically rich conference par excellence. Few innovations were tried which proved to be fruitful. Theme based IAP-AAP CME for academicians, essential CME for practitioners, a PG CME exclusively for exam going postgraduates and another $\mathrm{CME}$ for those who aim and strive to expand their wings as entrepreneurs. The main conference was studded with more and more "Interactive sessions", "Ask the experts", "Dialogues", "Debates", "Case-Scenarios" and "Keypad Sessions" rather than monologues which were applauded by one and all.

The theme of the conference was unique "Nurture with care-Save the girl child." It is a matter of shame that female feticide is still rampant in our country, resulting in gender disparity. As custodians of child health, it is the fundamental duty of all the pediatricians to care for and save the girl child and also prevent prenatal sex determination tests.

One of the many programs and projects envisaged under IAP Presidential Action Plan 2012 'Color Atlas Of Pediatrics' was the most cherished dream project of mine which got realized and released during PEDICON. This masterpiece creation of international class has been very artfully crafted into a pictorial catalogue, covering almost the entire Pediatric science in its fold, probably first of its kind in the world. It has undoubtedly become an academic asset for IAP. I am indeed indebted and grateful to the contributors, 36 section editors, 7 editorial board members and of course the editor-in-chief, veteran Dr A
Parthasarathy, who is the main architect of this project. This color atlas would be a ready reckoner for practicing pediatricians, a library companion for academicians and very useful for the postgraduate students. My heartfelt thanks go to Jaypee Publication House for engineering this publication within a very short time of six months.

Apart from CAP, another very important book released was "Advances in Pediatrics" published by the organizers of PEDICON under the editorship of Dr Anupam Sachdev. Few other very good books included the one on 'Disability' by Dr Anju Aggarwal and 'Nephrology' by Dr Anand Vasudev. The $5^{\text {th }}$ Edition of IAP Textbook of Pediatrics and other IAP sub-specialty books are in the pipeline waiting to see the light of the day during next Golden Jubilee PEDICON. I am indeed privileged and proud to head such an organization which has academically surpassed far ahead of all other medical societies in the country. However this excellence in academics should get translated into rationality in management and better child health care so that a major chunk of child mortality can be reduced. The issues concerning parent education were diligently addressed by celebrities like Shyam Benegal, Nazma Heptullah and Supriya Sule.

A very promising partnership was forged between IAP and Government of India in the form of "Private-PublicPartnership (PPP)"which will go a long way in the health delivery system of the country particularly towards sick and needy children, thereby giving a push towards achievement of MDG-4. To achieve MDG-4 by reduction in child mortality and reaching the unreached pediatricians through academics are the main goals of IAP this year. I shall address these issues in the next issue of Indian Pediatrics. Till then, Goodbye to you all......

Rohit Agrawal National President 2012, Indian Academy of Pediatrics drrohitag@gmail.com 